\title{
CANNAbis Production AND land USE PlanNing: A literature ReView
}

\author{
Mathew V. Vaughan ${ }^{\mathrm{a}}$, Jeremy Pittman ${ }^{\mathrm{a}}$ (D), Sara Epp ${ }^{\mathrm{b}}$ (D) and Wayne Caldwell ${ }^{\mathrm{b}}$ \\ ${ }^{a}$ University of Waterloo \\ ${ }^{\mathrm{b}}$ University of Guelph
}

\begin{abstract}
Résumé
Les normes de production du cannabis évoluent avec peu de données expérimentales sur les impacts dans l'aménagement du territoire. Santé Canada administre un système de licence désuet qui ne traite pas des questions d'odeur nauséabonde ou encore de la pollution lumineuse qui représentent toutefois des effets préoccupants sur le paysage rural. Ce compte-rendu examine l'histoire de la réglementation régissant la production du cannabis au Canada. De plus, cette analyse comprative met en évidence les incohérences du système de législation fédérale relatives aux permis de production de cannabis. Cette étude révèle les conflits de loi en souligant les facteurs comme les odeurs fortes et la lumière puissante émanant des installations de production. Les entreprises opérationelles dans le marché du cannabis seront également étudiées à des fins effective.

Mots-clés: cannabis, production du cannabis, zonage de la culture de cannabis, conflit sur l'utilisation des terres, histoire du cannabis, odeur du cannabis, émissions lumineuses, pollution lumineuse, contrôle des odeurs, réglementation des odeurs, Formules de calcul des distances minimales de séparation (DMS)
\end{abstract}

\section{Abstract}

Cannabis production standards are evolving with little understanding of their implications on land use planning. Health Canada currently administers a federally-regulated licensing system that does not address odour and light pollution land use impacts across the rural landscape. This literature review addresses the regulatory history of cannabis production in Canada, reviews current production standards, and compares possible cannabis production conflicts with documented land use conflicts from other odourous and light intensive operations to reveal flaws in the existing licensing system. Established cannabis production markets will be examined for further comparisons.

Keywords: cannabis, cannabis production, cannabis zoning, land use conflict, cannabis history, cannabis odours, light emissions, light pollution, odour control, odour regulation, MDS formulae

Canadian Planning and Policy/Aménagement et politique au Canada, Volume 2021, pages 131-145.

This work is licensed under a Creative Commons Attribution 4.0 International License.

ISSN 2562-122X

DOI 10.24908/cpp-apc.v2021i01.14093

CIP-ICU \& ACUPP-APUCU

Canadian Planning and Policy 2021 


\section{INTRODUCTION}

Cannabis production is a relatively new land use phenomena in the world of planning. Unlike other forms of horticultural and agricultural use, cannabis production offers an array of land use conflicts including odour and light emissions. While there exists several land use planning tools capable of mitigating these issues, it is not clear what measures should be taken to ensure a fair and equitable regulatory system. To date, research has been conducted on the citing of medical cannabis dispensaries, but is lacking in relation to production land use standards (Freisthler et al., 2013; Németh \& Ross, 2014).

Legal cannabis production across Canada started taking form in 2001. After a number of regulatory and legislative changes aiding in its recreational legalization and medical access, cannabis production has experienced a boom. As of January 2021, there were 581 cultivators, processors, and sellers across Canada that hold a commercial license issued by Health Canada (Government of Canada, 2021). Additionally, as of September 2020, there were 43,211 personal or designated production registrations with Health Canada. That is $67 \%$ higher than roughly two years earlier as illustrated in Table 1 (Government of Canada, 2021).

As cannabis production gains traction across Canada, there is an immediate need to address the land use conflicts that accompany it. Does a new form of land use regulation need to be created to address the shortcomings of cannabis production or is there an existing option already available to solve this malodourous issue?

In Ontario, various provincial guidelines and criteria have been developed to address land use conflict between disruptive and sensitive land uses. As cannabis use across Canada becomes more widely accepted as a cultural normality, production standards are developing with very little consideration to land use planning and the effects production has on surrounding properties. What started as a response to alternative medical treatments originating from eastern medicine practices (Zuardi, 2006) has resulted in a federally regulated archaic licensing system struggling to maintain compliance (Vaughan, 2018). This system now threatens to cause a new form of land use conflict across the rural landscape unless land use regulations are implemented.

Within the last ten years, cannabis production regulations have dramatically changed. The MMAP evolved into the MMPR, which seemingly devolved into the ACMPR leading to the Cannabis Act. Despite there being no sound evidence to correlate physical health issues with cannabis production related odours, there is an apparent correlation between production odours and the stress and mental health implications it has on neighbouring property owners (Sedlock \& Settelmeyer, 2017). The future of cannabis land use planning will be determined by comprehensive planning principals that consider not only maintaining access to medical cannabis, but also a regulatory framework that protects property rights for surrounding property owners. As a world leader in legal cannabis

Table 1. Personal or designated production registration with Health Canada

\begin{tabular}{|l|l|l|l|l|l|l|l|l|l|l|l|l|l|l|}
\hline Date & CAN & AB & BC & MB & NB & NL & NS & NT & NU & ON & PEI & QC & SK & YK \\
\hline $\begin{array}{l}\text { October } \\
\mathbf{2 0 1 8}\end{array}$ & 25,945 & 3,143 & 5,747 & 921 & 850 & 140 & 1,183 & 5 & 0 & 9,037 & 56 & 4,424 & 425 & 14 \\
\hline $\begin{array}{l}\text { September } \\
\mathbf{2 0 2 0}\end{array}$ & 43,211 & 4,473 & 8,590 & 1,985 & 1,181 & 326 & 1,520 & 7 & 0 & 14,648 & 89 & 9,773 & 596 & 23 \\
\hline $\begin{array}{l}\text { Percentage } \\
\text { change }\end{array}$ & $+67 \%$ & $+42 \%$ & $+49 \%$ & $+115 \%$ & $+40 \%$ & $+133 \%$ & $+28 \%$ & $+40 \%$ & $0 \%$ & $+62 \%$ & $+60 \%$ & $+121 \%$ & $+40 \%$ & $+64 \%$ \\
\hline
\end{tabular}

(Government of Canada, 2021) 
production, Canada is situated to set the global industry standard if its regulatory system is capable of maintaining order.

Through the review of peer-reviewed journal articles, academic published books, and government related web-based data sources, this literature review focuses on a series of topics related to cannabis production. The review starts by examining the history of cannabis production in Canada and assesses the plant's production practices. Two global comparisons are examined from Uruguay and the United States. Four malodourous land uses are also examined to study comparable land use setback regulations. A brief review of literature related to the measurement of odour and the ill-effects of light emission exposure are highlighted. Finally, the review concludes by summarizing the literature findings.

The literature review has revealed that the current regulatory framework for cannabis production does not adequately enable consistent land use controls to address odour related concerns. Given the apparent land use conflicts imposed by the cannabis production industry, it is clear that a standard form of land use regulations must be created to govern all forms of cannabis production.

\section{Canadian Planning System}

The Canadian land use planning system is built on a two, (sometimes three) tiered system approach depending on local governments. Land use planning is governed by provincial legislation (such as Ontario's Planning Act and Provincial Policy Statement). Municipal councils adopt land use plans such as an Official Plan or Secondary Plans, which are approved by the Province. Municipalities are then responsible for enacting Zoning By-Laws to control land use planning and development within their jurisdiction (Osler, Hoskin \& Harcourt LLP, 2021). The federal government, however, is not involved in land use planning but rather facilitates policy and regulatory development (Grant et al.,
2013). This hierarchy can lead to administrative and land use challenges for Health Canada when regulating the cannabis production industry.

At the provincial level, planning tools such as guidelines and provincial plans can be used to regulate specific forms of land use patterns. For instance, in Ontario, the province uses the Minimum Distance Separation Formula to regulate livestock facilities which are known for their off-putting odours and conflicts with adjacent land uses (Caldwell \& Toombs, 2000).

Cannabis production in Canada is regulated at the federal level through Health Canada. The production of cannabis in Canada has a long history that is important to consider in order to understand the shortcomings of the existing land use regulatory framework.

\section{History of cannabis production in Canada}

Cannabis ${ }^{1}$ first became an illegal substance in Canada in 1923 when it was added to the registered list of illegal substances as part of the Opium and Narcotic Drug Act (Hewitt, 2004). Nearly 95 years later, Canada is now the second country in the world to legalize the production, sale, and use of medical and recreational cannabis (Cox, 2018). The road to legalization was relatively brief. In 2001, Canada established the Marihuana Medical Access Program (MMAP) (Government of Canada, 2016). The MMAP introduced cannabis as a prescription drug through the Board of the College of Physicians and Surgeons and the Canadian Medical Protective Association (College of Physicians and Surgeons of British Columbia, 2016). Through the MMAP, patients could either produce their own cannabis, designate a person to grow it for them, or obtain it through a licensed grower (Government of Canada, 2016), and thus was born Canada's first legal cannabis production sites.

However, the MMAP regulations did not last long,. In June 2013, after a number of superior court

\footnotetext{
${ }^{1}$ The term cannabis is used in place of marihuana, or marijuana, and is defined as a genus of flowering plants in the family Cannabaceae but does not include the industrial or agricultural production of hemp (a source of foodstuffs (hemp milk, hemp seed, hemp oil), fiber, and biofuels) (Norfolk County, 2014).
} 
rulings, the Canadian federal government launched the Marihuana for Medical Purposes Regulations (MMPR). According to Reid and Dykstra (2016), the MMPR removed the "inherent risks associated with patients growing marijuana at home such as the risk of fire, mold, and break-ins, for better quality control, and to delegate the responsibility of growing and supplying marijuana as Health Canada had become unable to keep up with increasing demand" (p. 1).

In 2016 a constitutional challenge (Allard et al. v. Canada) determined that the MMPR was too restrictive (CanLII, 2019). This led to the passing of the Access to Cannabis for Medical Purposes Regulations (ACMPR); a licensing system that resembled the MMAP, where a medically prescribed cannabis user could obtain registration from Health Canada to produce/cultivate their own medical cannabis. As a result, the ACMPR created two streams of medical cannabis production; Part 1 , which enables Licensed Producers (LPs) to obtain commercial medical licensing, and Part 2, which enables a medically prescribed individual to obtain a registration to grow their own medical cannabis, or designate another person to grow it for them (Government of Canada, 2016). On October 17, 2018 the Liberal government passed the Cannabis Act, repealing the ACMPR regulations, but in doing so, brought forward many of the same regulations in relation to licensed and personal medical cannabis production (Government of Canada, 2018).

Today, the licensing system for LPs remains robust, taking into account many details about the production, security, and dispersion of cannabis (Vaughan, 2018). Presently, Health Canada permits three forms of cultivation: standard cultivation, micro cultivation, and nursery. A detailed description of how each of these forms of cultivate works is described in Table 2.

Table 2. The subclasses of licensed cannabis production

\begin{tabular}{|c|c|c|}
\hline Subclass & Restrictions & Notes \\
\hline Standard Cultivation & - No size limitations & $\begin{array}{l}\text { An applicant may apply for a standard cultivation license, even with } \\
\text { a proposed plant surface area of less than } 200 \mathrm{~m}^{2} \text { but standard } \\
\text { cultivation requirements will apply in this case } \\
\text { Cultivation may be conducted indoors or outdoors }\end{array}$ \\
\hline Mirco-cultivation & $\begin{array}{l}\text { - Plant surface area cannot } \\
\text { exceed } 200 \mathrm{~m}^{2} \text { (includes } \\
\text { multiple surfaces such as } \\
\text { surfaces vertically arranged) }\end{array}$ & $\begin{array}{l}\text { Cultivation may be conducted indoors or outdoors but the cannabis } \\
\text { plant surface area includes any indoor/outdoor areas at any single } \\
\text { time) }\end{array}$ \\
\hline Nursery & $\begin{array}{l}\text { - For seed production, total } \\
\text { surface area of no more than } 50 \\
\mathrm{~m}^{2} \text { must contain all the parts of } \\
\text { budding or flowering plants } \\
\text { - Maximum of } 5 \mathrm{~kg} \text { of flowering } \\
\text { heads harvested from plants } \\
\text { with the exception of seeds } \\
\text { - Must destroy the flowering } \\
\text { heads (with the exception of } \\
\text { the cannabis plant seeds), } \\
\text { leaves and branches of the } \\
\text { plants within } 30 \text { days of } \\
\text { harvesting them }\end{array}$ & Cultivation may be conducted indoors or outdoors \\
\hline
\end{tabular}

(Government of Canada, 2021) 
Health Canada's personal stream of production facilities are outpacing licensed facilities in both size and product output (Government of Canada, 2019). The chief concern with these unregulated personal production facilities relates to the odours they are emitting, affecting neighbouring property owners' quality of life (Vaughan, 2018). It appears federal regulations are not effective at ameliorating local impacts in comparison to land use planning tools such as the provincial MDS guidelines or D6 guidelines. While federal regulations focus mainly on licensing cannabis production and processing facilities, they can stand to learn from existing provincial guidelines by putting more emphasis and legal standing on municipal policy tools.

\section{UNDERSTANDING THE GROWTH HABITS OF Cannabis}

In order to understand the land use implications of cannabis production, it is necessary to understand how it is produced. Cannabis can be grown in a variety of substrates, including but not limited to soil, vermiculite, perlite, and liquid mediums and can be grown both outdoors (seasonally), and indoors (year-round) (Cyrenne \& Shanahan, 2018). Both forms of production have their strengths and weaknesses.

\section{Indoor production}

Indoor production variables such as moisture, light and air cooling, and circulation can be controlled with more accuracy and more predictability in comparison to outdoor production (Cervantes, 2002; Chandra et al., 2017). In addition, indoor production can benefit from a cleaner environment with less incidence of microbial contamination, translating to less product loss and less need for fungicides. Indoor production can also benefit from vertical or strata-production practices, meaning multiple storeys of production resulting in less need for space with a smaller building footprint. Some evidence suggests these vertical cannabis farms offer many advantages as a clean and green source of cannabis, along with biosecurity, freedom from pests, droughts, and reduced use of transportation and fossil fuels (Benke \& Tomkins, 2017). There is also the benefit of being able to grow year-round. The main challenge with indoor production is cost, as there are large expenditures associated with building construction, hydro requirements, and the cost associated with operating optimum growing conditions such as temperature, moisture, odour, and microbial control (Cervantes, 2002). From a land use perspective, indoor production offers less incidences of land use conflict when controls on light and odour emissions are implemented.

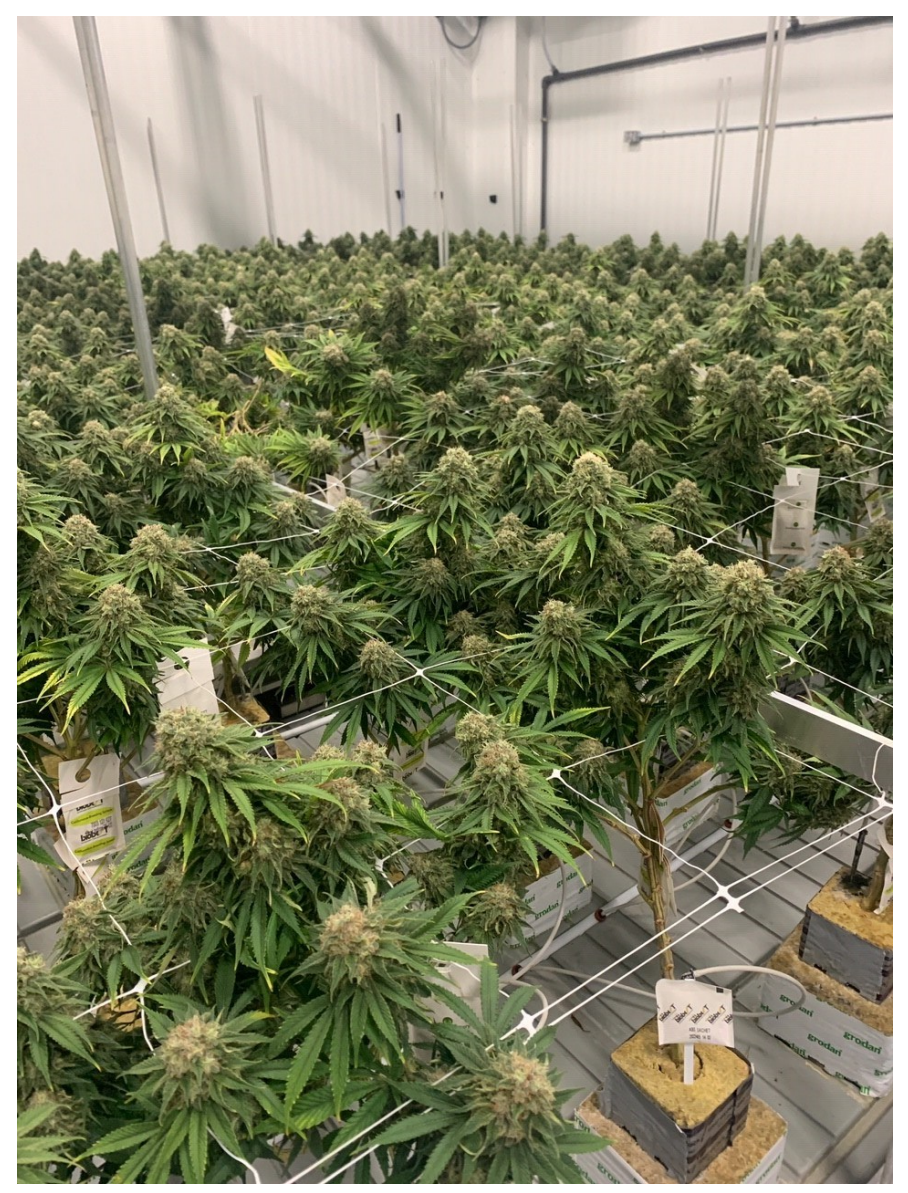

Figure 1. Indoor production.

\section{Outdoor production}

Outdoor cannabis production benefits from a significant cost savings due to minimal expenditures (Caulkins, 2010), yet suffers from a lack of control over growing conditions. Contamination and seasonal-production timeframes remain the largest drawbacks (Potter, 2014). 
In relation to land use planning, outdoor production can lead to complaints regarding odour emissions (Sedlock \& Settelmeyer, 2017). However these emissions are typically seasonal as well.

\section{Hybrid production system}

Hybrid cannabis production systems use a combination of outdoor and indoor growing conditions. An example of such a facility would include a hoop-house, or non-heated/cooled greenhouse. In this scenario, the cannabis plants remain covered, and semi-protected from the elements, but still benefit from sun exposure. These systems take advantage of both reduced costs and favorable growing conditions, but remain limited by the length of the growing season depending on their geographic location. Despite this limitation, some greenhouses are capable of producing three harvests per year in comparison to four harvests for indoor production (Cervantes, 2002). Some hybrid systems include indoor lighting to lengthen their growing season.

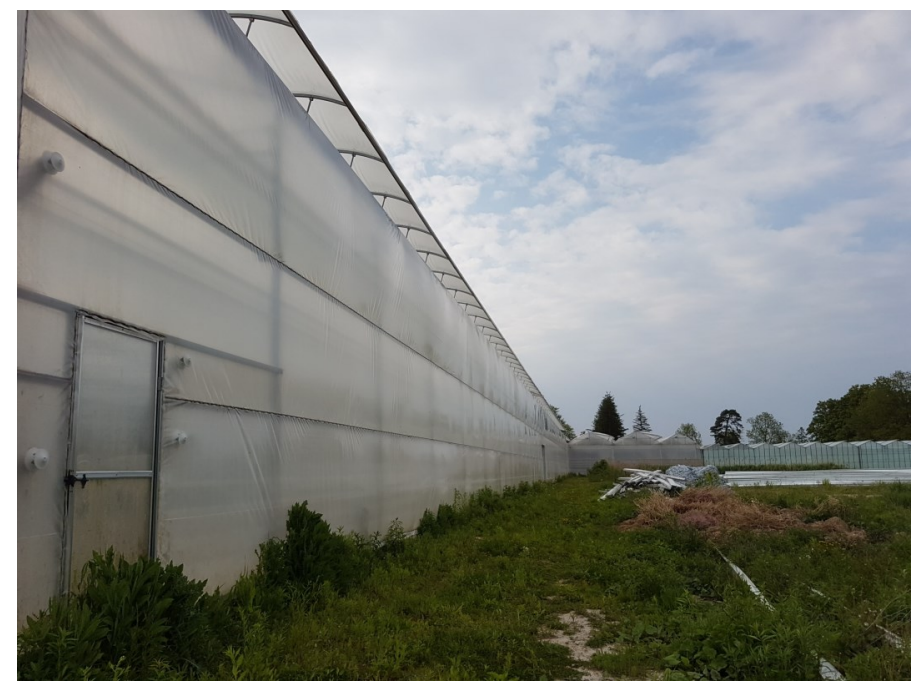

Figure 2. Hybrid production facility.

From a land use planning perspective, hybrid production systems offer the same land use conflicts as what outdoor production does in terms of odour, but can also add the issues of noise and light pollution where indoor lighting and exhaust fans are used to expel excess heat. Consequently, the hybrid production system may impose the highest level of land use conflict to adjacent properties. Based on observations of a sample of hybrid facilities located in Norfolk County, Ontario, most hybrid systems within this jurisdiction do not contain air filtration (Vaughan, 2018). Due to their semi-confined space, more research is required to determine if hybrid production systems offer higher concentrations of odour emissions than outdoor production systems.

\section{Health implications of CanNabis production AND THE NECESSITY OF REGULATION}

Odour emissions are among the chief concerns from neighbouring property owners. However very little research has been conducted to date in relation to cannabis production odours and human health (Steiner, 2018). No studies on the health effects associated with exposure to cannabis odours have been identified in scientific or grey literature (Public Health Ontario, 2018). In general, odour exposure is considered only a nuisance problem. However, it has recently been acknowledged that it can also negatively affect human health through irritation or psychopathologic mechanisms (Schiffman \& Williams, 2005; Shusterman, 1999). Moreover, related to odour, a recent study from Islamabad, Pakistan shows that due to the size of the cannabis pollen molecule, the cannabis plant could be a potent allergenic pollen-producing weed that might cause serious health problems (Shinwari et al., 2015). It should be noted that this study is based on the presence of wild hemp (the male equivalent to cannabis), and not the female cannabis plant that is cultivated for its high THCA values. ${ }^{2}$

There are some parallels that can be drawn between cannabis production and other odourous land uses. Firstly, it is important to understand that not all odours are equal. The odours expelled from the cannabis plant are related to the release of volatile organic compounds (VOCs) in the air (Public Health Ontario, 2018). Rice and Koziel (2015) conducted a study that identified over 200 unique VOCs from cannabis samples. Despite the plant's

\footnotetext{
${ }^{2}$ Tetrahydrocannabinolic acid (THCA) is the non-psychoactive molecule of the cannabis plant.
} 


\section{Cannabis production land use planning in Canada}

high VOC range, most outdoor odours are generally not toxic enough to cause long-term effects to human health, but can effect one's quality of life. Certain forms of odour exposure can present physical symptoms in addition to mental health stress (Agency for Toxic Substances and Disease Registry, 2017). The size and scale of cannabis production correlate to the intensity of odour production (i.e., the larger the production is, the more potential it has to create odours). The form of cannabis production (outdoor vs. indoor with air treatment vs. hybrid with no air treatment) can influence odour detection. Therefore, it is probable that the form of cannabis production can influence the potential of health consequences. This is a particularly important consideration when siting a cannabis production operation with, or without adequate air treatment control. The only true means to determine health implications of odour complaints is to collect biomarkers of reported health symptoms and test them against environmental conditions (Schiffman \& Williams, 2005).

Outdoor and hybrid production systems expel not only specific cannabis related odours, but also excessive light and noise emissions. The vegetative cycle of the cannabis plant can require 18 to 24 hours of light (Lalge et al., 2017), emitting light pollution into the neighbouring properties past dusk. It is now accepted that artificial light has adverse effects on the natural environment and on human beings (Navara \& Nelson, 2007). According to Hölker et al. (2010), "night lighting may have serious physiological consequences for humans" (p. 1). Noise pollution is another form of unwanted emissions that can result from exhaust fans attached to cannabis production facilities. Goines and Hagler (2007) note that "the potential health effects of noise pollution are numerous, pervasive, persistent, and medically and socially significant" (p. 1) Excessive noise can disrupt sleep patterns, concentration, communication, and recreation leading to physical and mental stress (Goines \& Hagler, 2007).

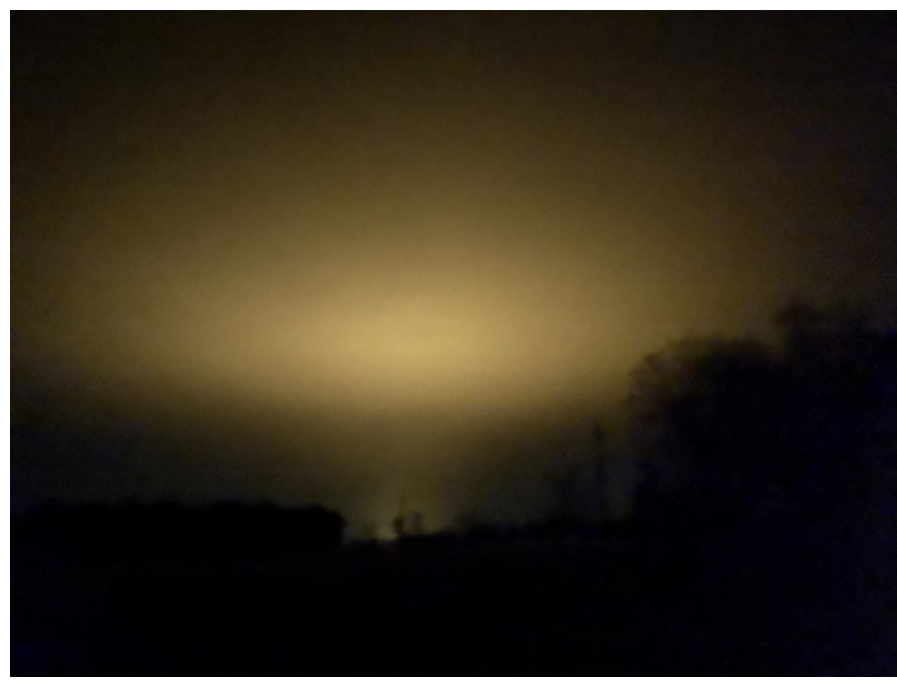

Figure 3. Light pollution.

A review of media resources related to cannabis production sites highlights neighbour complaints of excessive odour, light and noise emissions, and their accounts of headaches, cardiovascular distress, sleep deprivation, anxiety and overall poor mental health quality (Sedlock \& Settelmeyer, 2017; Stuart -Ulin, 2019). "Current production practices recommend the use of appropriate ventilation and filtration systems at cannabis production/cultivation facilities to mitigate the release of substances that may result in odours" (Public Health Ontario, 2018, p. 1). Furthermore, night-shading curtains can be used to alleviate light pollution nuisance (Coulter, 2017).

Despite the abundant correlating evidence related to cannabis production and its impact on human health, it should also be noted that exposure to VOCs (or terpenoids) in the natural environment can have beneficial impacts to human health as well (Frumkin, 2001). A study by Cho et al. (2017) shows the potential biological effectiveness of terpene use as chemotherapeutic agents for treating various human diseases.

At this time the current literature suggests that besides the creation of odour nuisance, there is no link between cannabis production odours and human health. Due to the lack of data, further research is required. Despite these findings, it is 
worth noting that odour nuisance from other forms of pollution sources such as livestock can negatively affect human mental health, and in some cases physical health (Nimmermark, 2004). In addition, there is a strong argument that light and noise emissions could affect the physical health of neighbouring property owners (Chepesiuk, 2009; Oiamo et al., 2015) which, suggests greater land use regulations should be reviewed to alleviate these conflicts.

\section{Global Cannabis Production Comparisons}

As of the end of 2019, legal recreational cannabis use and sales is limited to only Canada and Uruguay. Despite several states in the United States legalizing its use and sales, cannabis is still an illegal substance federally. Additionally, in Denmark, another country known for its cannabis liberalism, recreational cannabis use and sales remains federally illegal. A pilot program was initiated in Denmark in 2018 to experiment with legal medicinal use (Aguilar et al., 2018).

\section{Uruguay}

In 2013, Uruguay became the first country in the world to completely legalize the medical and recreational use of cannabis (Aguilar et al., 2018). Similar to the Canadian regulatory system, the Uruguayan federal government regulates the production, sale, and consumption of cannabis. Production is limited to personal production and to production clubs which are licensed to grow for the recreational and medical market. Uruguayan Cannabis Clubs (UCCs) are formed by up to 45 adults (Queirolo et al., 2016). There are a number of qualifications required to start and operate a UCC. In terms of setback controls, the club and growing facility (both indoor and outdoor) must meet a minimum distance of 150 metres from an educational facility for students under 18 and/or addiction treatment centers, and 1,000 metre separation between UCC facilities (Queirolo et al., 2016). Furthermore, clubs are only permitted to have up to 99 plants growing at a time (Walsh \& Ramsey, 2018). This is an important factor as this is considerably less plants in production when

compared to Canadian cannabis production sites that can have thousands of plants growing, producing thousands of kilograms at a time (Vaughan, 2018). The size and scale of commercial production between Canada and Uruguay is simply not comparable and therefore neither is the comparison of odour emissions.

\section{Mendocino County, California, United States}

Despite cannabis being federally illegal in the United States, there are more than 20 states that currently permit medicinal cannabis, and some that also permit its use recreationally (National Organization for the Reform of Marijuana Laws, 2019). In general, cannabis cultivation is regulated at both the municipal and state level, having different rules applied within each level of government (Salkin \& Kansler, 2010). In relation to cannabis production, much of the land use debate is centered on whether the product is considered an agricultural or industrial use. Depending on this classification, cannabis production is only permitted in agricultural or industrial zones (Salkin \& Kansler, 2010). Similar to Canada, some jurisdictions permit the production of cannabis for medical purposes. Despite a person's medical need, some local municipalities such as Mendocino County, California impose a limit on the area that is permitted to be in production. For instance, the personal medicinal size is limited to $\sim 9.3$ square (100 square feet) with a six plant maximum (for adult use). Commercial facilities are also permitted, with the largest facility area permitted up to 929 square metres (10,000 square feet), which may be subject to an air quality assessment (Mendocino County, n.d.). Furthermore, the cultivation of cannabis in any amount is required to be setback 305 metres (1,000 feet) from a youth-orientated facility, a school, or a park, and set back 30 metres (100 feet) from any legally occupied residential structure located on a separate lot. This setback has been approved to be increased to 61 metres (200 feet) as of January 2020 (Mendocino County, n.d.). 


\section{Comparable Odourous Uses}

Despite the lack of comparable federally legal cannabis regimes, another approach to cannabis production odour research is to compare cannabis production odours to other comparable odourous uses. Unpleasant environmental odours may cause severe conflicts to neighbouring uses resulting in the deterioration of quality of life, economic decline and devaluation of real estate (Gostelow et al., 2001). Due to the infancy of the legal cannabis industry, the data surrounding impacts of odours and light emissions are minimal; however, other forms of odourous and light intensive land uses can be explored to help inform cannabis production land use policy. For comparison purposes, four primary odourous uses will be reviewed including livestock facilities, anaerobic digesters, waste treatment facilities, and landfills. Additionally, a review of light emission exposure will aid in understanding the effects of excessive light pollution on surrounding land uses. Historically, each of these comparators have been scrutinized for their impacts to surrounding land uses, resulting in governmental intervention and regulation in the form of setback controls (Buffiere et al., 2008; Fraser, 2001; Lane \& McDonald, 1983; MacMillan \& Fraser, 2003).

\section{Livestock facilities}

In relation to land use conflict, the primary concern with livestock facilities is with the storage and spreading of manure leading to odours and in some cases drinking water contamination. There have been over 168 odorous volatile compounds recognized in livestock manures (Krishnan, 1995; Mahin, 2001; Zhang et al., 2002). According to Mahin (2001), the number of complaints across the world from livestock facilities is on the rise. This increase may be attributed to the increasing size and scale of such facilities (an adaption to compete with foreign markets to improve efficiency), or the increased incidence of having sensitive land uses in close proximity to a facility. As urban areas across the world continue their rapid expansion, the incidence of conflict between livestock operations and sensitive land uses will likely continue to rise. In the case of livestock facility conflict mitigation, each country has developed their own approach for how to best avoid conflicts (Mahin, 2001).

In Ontario, after years of odour driven complaints, and issues with water contamination, the Government of Ontario assumed responsibility for developing criteria for prescribing separation distances between livestock facilities and sensitive land uses like residential development. The first version of a minimum distance separation formulae (MDS formulae) was drafted in 1973 and introduced in 1976. It implemented a mutual sliding scale method to separate livestock facilities from non-compatible uses such as residential development. Unlike the formulae's predecessor which used fixed distances, the MDS formulae resulted in greater setback distances between the two conflicting uses depending on the size and scale of the facility and the type of animal housed there (Fraser, 2001). The formulae uses a series of factors including the type of livestock, the capacity of facility (which includes reference to the size of the facility or lot size), and the type of manure system and storage. The formulae also accounts for the type of land use adjacent to the operation, and then calculates a specific distance the facility needs to be placed away from a specific point of potential conflict (Government of Ontario, 2019). Since its inception, the MDS formulae (or a version thereof) has been copied and used across Canada showing its overall effectiveness at mitigating conflicting land uses. Despite its uptake, the MDS formulae is not perfect. According to MacMillan and Fraser (2003), the system is "unable to quantitatively account for odour control technologies, such as biofilters and manure treatment systems" (p. 1). Although once added into planning documents the addition of certain technologies has provided the basis for minor variances in some situations

\section{Anaerobic Digesters}

In its simplest form, anaerobic digesters convert organic compounds into biogas and energy. The digesters can benefit the agricultural industry by removing odourous volatile compounds from animal waste so that its application as fertilizer is less invasive to surrounding sensitive land uses 
(Ritter, 1989). Despite this benefit to the agricultural industry, the digesters expel large plumes of odours of their own from this process. Several jurisdictions around the world categorize anaerobic digesters and livestock facilities together under the same umbrella of incompatible land uses due to their odour occurrence (Banks et al., 2007). Consequently, digesters land use controls and separation requirements are similar to that of livestock facilities.

In Ontario, anaerobic digesters are regulated by the MDS formulae (Government of Ontario, 2019).

\section{Sewage treatment facilities}

Sewage treatment facilities are known sources of offensive odours, especially when operations and maintenance are not adequate, or when weather conditions are not favorable (Stellacci et al., 2010). Weather patterns play a role in the detection of these odours at different distance intervals. According to Stellacci et al. (2010), several studies have shown that living near a sewage treatment facility can lead to negative human health implications including "nausea, headache, lack of appetite and, more rarely, other acute and even chronic health effects" (p. 51). This points to a correlation between the waste water treatment facility odours and the symptoms experienced by neighbouring property owners (Stellacci et al., 2010).

In Ontario, sewage treatment facility setback controls are regulated by the Ministry of Environment, Conservation and Parks, and more specifically, by the Design Guidelines for Sewage Works (Ministry of the Environment Sewage Technical Working Group, 2019). The guidelines do not explicitly require any set distance requirement from an adjacent sensitive land use, but rather requires technical reports and studies on a case-bycase basis. As a result, each facility will be designed and setback according to its location, size and operational and maintenance requirements (Ministry of the Environment Sewage Technical Working Group, 2019).

\section{Landfills}

Due to their long-term decomposition rates, landfills are a source of constant odour emissions (McKendry et al., 2002). Odours emanating from landfills is the result of the aerobic and anaerobic decomposition of waste materials into gaseous volatile compounds such as methane, oxygenated compounds and hydrocarbons, components known to be malodorous (Duan et al., 2021). Typically, landfills are located on the periphery of urban settlements, downwind from known sensitive land uses (Lane \& McDonald, 1983).

In Ontario, landfill site setback controls are regulated by the Ministry of the Environment, and more specifically, by the Landfill Standards Guideline, which is a guideline on the regulatory and approval requirements for new or expanding landfilling sites (Ontario Ministry of Environment, 2012). Similar to sewage treatment facilities, landfill site section is not explicitly identified in the Landfill Standards Guideline, but rather requires technical reports and studies on a case-by-case basis (Ontario Ministry of Environment, 2012).

There are some lessons to be drawn from reviewing the four comparable odourous land uses in relation to cannabis production regulations. Of the different forms of malodourous uses identified through this review, livestock facilities and anaerobic digesters require specific setback controls based on a prescribed formulae dictated by a set of land use criteria. In relation to industrial uses in Ontario, separation distance is an important factor in the issuance of an Environmental Compliance Approval. The MDS formulae provides an appropriate tool for regulating setback requirements from a malodourous use. The required setback is based on a number of inputs including size, scale, and surrounding uses. Given its history and since cannabis production is more akin to agricultural uses than it is to industrial uses (Owens, 2019), the scientific framework that was used to develop the MDS formulae for livestock and anaerobic digesters may be considered for cannabis production setback regulations. Any form of setback controls should be scientifically organized to help mitigate odours. To 
ensure consistency, how odour is measured must be considered. The literature surrounding the measurement of cannabis production odours is limited and therefore, a scientific method for cannabis production odour measurement requires further investigation.

\section{Measuring Odour}

Before odours can be mitigated, they first need to be understood, which requires some level of quantitative analysis. However, developing an effective odour measurement tool is both challenging and problematic. The human sense of smell is quite subjective, and even the most trained noses struggle to maintain consistency as the memory of smell is sometimes fleeting (Engen et al., 1973). It is essential to utilize a sciencemodelled basis for developing setback distances from malodourous land uses. A standardized odour modelling system could help to develop policies for establishing cannabis production setbacks, similar to how setbacks have been developed for livestock facilities, anaerobic digesters, sewage treatment facilities and landfills. Besides the human nose, there are a multitude of methods employed to assess odour emissions and the odour annoyances to surrounding properties. Three key methods include chemical analysis, dynamic olfactometry, and electronic noses (Romain et al., 2008).

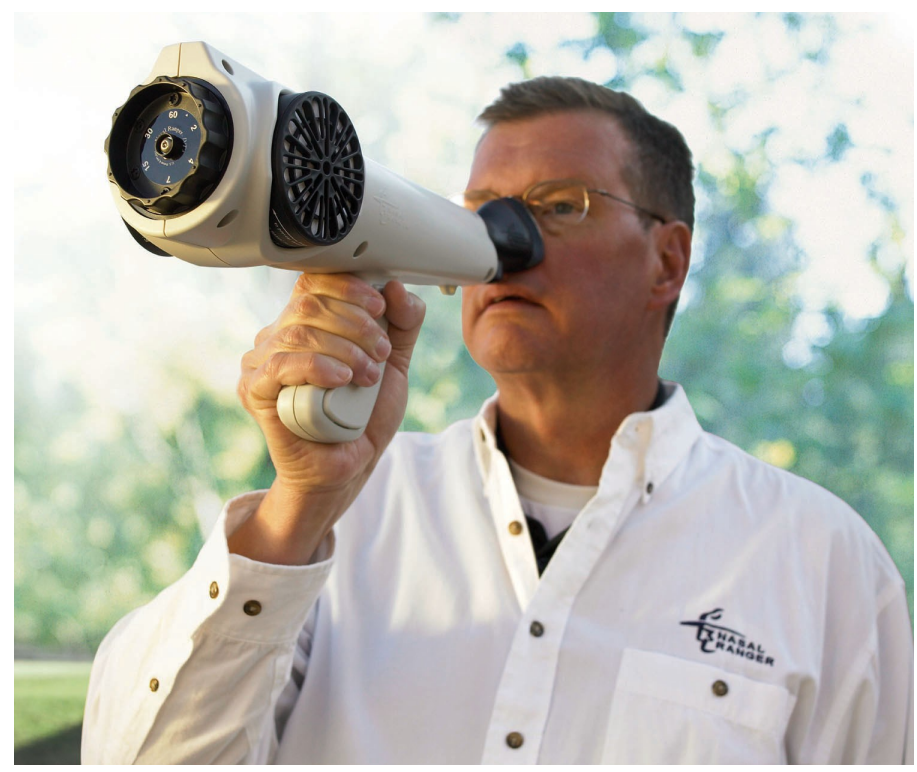

Figure 4. Nasal ranger.
Chemical analysis includes a laboratory analysis to quantitatively assess odour intensity, composition and character including the determination of the chemical species (odorants) (Parcsi, 2010). Dynamic olfactormetry supplements the human nose with a tool called an olfactometer which works by diluting an odour sample with odour-free air, according to precise ratios to determine odour concentrations (Brattoli, et al., 2011). Electric noses are intended to mimic the sensory detection levels of the human nose and include a multitude of sensors, receptors, and processors (Persaud \& Dodd, 1982) aimed at removing the subjectivity and ambiguity of natural odour detection (Romain et al., 2008). No one method is perfect, and a combined approach may prove to be the most useful in developing a sound scientific odour modelling system.

In addition to odour emissions, some forms of cannabis production are guilty of excessive light emissions. These emissions, while a by-product of production, increase the overall land use conflict imposed on surrounding neighbours contributing to the incompatibility between cannabis production facilities and the rural countryside.

\section{ILL-EFFECTS OF LIGHT EMISSION EXPOSURE}

Not all light is created equal. Some forms of light are used to illuminate space to extend hours of output, while others are used for safe travel. In regard to agriculture, specific wavelengths of light are used in the production of crops. This is easily observed in the rural countryside past dusk by the presence of light emanating from greenhouse facilities. This form of light can take on a different persona when it is received as being light pollution. Chepesiuk (2009) refers to light pollution as light that is perceived as being inefficient, annoying and unnecessary. Many bodies of research have shown light pollution to be one of the planet's most increasing forms of environmental concern (Falchi et al., 2011). Moreover, the latest research shows that light pollution has become a public health issue, with links contributing it to cancer formation (Pauley, 2004). 


\section{Cannabis production land use planning in Canada}

Indoor cannabis production requires the use of artificial lights. While some growers use factorytype buildings that are completely opaque, others employ the use of greenhouses. In relation to light pollution, the main concern with greenhouse cannabis production is that the shell of the building is often semi-transparent allowing reflected light to escape as light pollution into the surrounding atmosphere and into neighbouring properties. Despite there being an option to shade in the reflected light, not all growers willingly use this feature since it adds to the overall capital investment for production. Thus, there remains a significant source of light pollution from the production of cannabis if grown in greenhouses. To date, very little research exists in relation to the effects of light pollution from greenhouse cannabis production.

\section{Conclusion}

One of the purposes of land use planning is to ensure compatibility between adjacent uses to avoid conflict and foster cohesiveness (Van Lier, 1998). To date, research has been conducted on the siting of medical cannabis dispensaries, but is lacking in relation to production land use standards (Freisthler et al.,2013; Németh \& Ross, 2014).

In Ontario, various provincial guidelines and criteria have been developed to address land use conflict between disruptive and sensitive land uses. Today, a new form of pharmaceutical agriculture has emerged bringing with it similar conflicts resulting from odour and light emissions. As cannabis use across Canada becomes more widely accepted as a cultural normality, production standards are developing with very little consideration to land use planning and the effects production has on surrounding properties. What started as a response to alternative medical treatments originating from eastern medicine practices (Zuardi, 2006) has resulted in a federally regulated licensing system struggling to maintain compliance (Vaughan, 2018). This system now threatens to cause land use conflict across Canada's rural landscape unless land use regulations can be imposed to prevent further conflict.
Within the last ten years, cannabis production regulations have dramatically changed. The MMAP evolved into the MMPR, which seemingly devolved into the ACMPR leading to the Cannabis Act. Despite there being no sound evidence to correlate physical health issues with cannabis production related odours, there is an apparent correlation between production odours and the stress and mental health implications it has on neighbouring property owners (Sedlock \& Settelmeyer, 2017). The future of cannabis land use planning will be determined by comprehensive planning principals that consider not only maintaining access to medical cannabis, but also a regulatory framework that protects property rights for surrounding property owners. As a world leader in legal cannabis production, Canada is situated to set the global industry standard if its regulatory system is capable of maintaining order. To help, the federal cannabis production licensing system can learn from the provincial and municipal regulation of other noxious agricultural uses. The federal government could assist its provinces and municipalities by commissioning research on appropriate land use separation requirements such as the MDS formulae, as the province of Ontario did for livestock facilities in the past. Four malodourous land uses have been examined to study comparable land use setback regulations. Of these, the MDS formulae appears to represent the most comparable system to emulate, however more data is required to better understand how cannabis production odours should be measured.

The current regulatory framework for cannabis production does not adequately enable consistent land use controls in order to address odour related concerns. Given the apparent land use conflicts imposed by the cannabis production industry, it is clear that a standard form of land use regulations must be created to govern all forms of cannabis production. 


\section{NOTES ON CONTRIBUTORS}

Mathew (Mat) Vaughan, is a $\mathrm{PhD}$ student at the University of Waterloo and active registered professional planner in Ontario, Canada. Mat's academic focus is on cannabis production land use planning. Mat has been pivotal in the creation of one of Ontario's first comprehensive municipal policies for cannabis production and processing.

Jeremy Pittman is an Assistant Professor in the University of Waterloo's School of Planning. His research focuses on environmental governance and policy, and he works with a diverse range of communities and sectors in Canada and internationally on sustainability-oriented projects.

Sara Epp is an Assistant Professor in Rural Planning and Development at the University of Guelph. Sara's research has examined farmland loss, agricultural viability, land use conflicts and social aspects of rural life. Her current research interests include rural land use planning, agri-food systems, migration, and food security.

Wayne Caldwell is a Professor in Rural Planning and Development at the University of Guelph and a Registered Professional Planner / Fellow of the Canadian Institute of Planners. $\mathrm{He}$ is also a passionate advocate for the betterment of rural communities and has served as Chair/President of a number of local, provincial and national organizations.

\section{CORRESPONDING AUTHOR}

Mathew V. Vaughan, BES, MPlan, RPP, MCIP, CMMIII

University of Waterloo

Email: mvvaughan@uwaterloo.ca

\section{REFERENCES}

Agency for Toxic Substances and Disease Registry. (2019). Factsheet: Are environmental odors toxic? Atlanta, GA.

Aguilar, S., Gutiérrez, V., Sánchez, L., \& Nougier, M. (n.d.). Medicinal cannabis policies and practices around.
London, UK: International Drug Policy Consortium.

Banks, C. J., Salter, A. M., \& Chesshire, M. (2007). Potential of anaerobic digestion for mitigation of greenhouse gas emissions and production of renewable energy from agriculture: Barriers and incentives to widespread adoption in Europe. Water Science and Technology, 55(10), 165173. https://doi.org/10.2166/wst.2007.319

Benke, K., \& Tomkins, B. (2017). Future food-production systems: Vertical farming and controlled-environment agriculture. Sustainability: Science, Practice and Policy, 13(1), 13-26. https:// doi.org/10.1080/15487733.2017.1394054

Brattoli, M., De Gennaro, G., De Pinto, V., Demarinis Loiotile, A., Lovascio, S., \& Penza, M. (2011). Odour Detection Methods: Olfactometry and Chemical Sensors. Sensors, 11(5), 5290-5322. https://doi.org/10.3390/ $\underline{\mathrm{s} 110505290}$

Buffiere, P., Delgadillo Mirquez, L., Steyer, J. P., Bernet, N., \& Delgenes, J. P. (2008). Anaerobic Digestion of Solid Wastes Needs Research to Face an Increasing Industrial Success. International Journal of Chemical Reactor Engineering, 6(1). https://doi.org/10.2202/1542-6580.1619

Caldwell, W., \& Toombs, M. (2000, July). Planning and Intensive Livestock Facilities: Canadian Approaches.

CanLII. (2019, June 21). Access to Cannabis for Medical Purposes Regulations, SOR/2016-230.

Caulkins, J. P. (2010). Estimated Cost of Production for Legalized Cannabis. RAND, Drug Policy Research Center.

Cervantes, J. (2002). Indoor Marijuana Horticulture: The Indoor Growers Bible. Vancouver, WA: Van Patten.

Chandra, S., Lata, H., ElSohly, M. A., Walker, L. A., \& Potter, D. (2017). Cannabis cultivation: Methodological issues for obtaining medical-grade product. Epilepsy \& Behavior, 70, 302-312. https://doi.org/10.1016/j.yebeh.2016.11.029

Chepesiuk, R. (2009). Missing the Dark: Health Effects of Light Pollution. Environmental Health Perspectives, 117 (1), A20-A27. https://doi.org/10.1289/ehp.117-a20

Cho, K. S., Lim, Y., Lee, K., Lee, J., Lee, J. H., \& Lee, I.-S. (2017). Terpenes from Forests and Human Health. Toxicological Research, 33(2), 97-106. https:// doi.org/10.5487/TR.2017.33.2.097

College of Physicians and Surgeons of British Columbia. (2016). Practice Standard: Cannabis for Medical Purposes.

Coulter, L. (2017, March 13). Optimizing use of your curtains.

Cox, C. (2018). The Canadian Cannabis Act legalizes and regulates recreational cannabis use in 2018. Health Policy, 122(3), 205-209. https://doi.org/10.1016/ j.healthpol.2018.01.009 
Cyrenne, P., \& Shanahan, M. (2018). Toward a Regulatory Framework for the Legalization of Cannabis: How Do We Get to There from Here? Canadian Public Policy, 44(1), 54-76.

Duan, Z., Scheutz, C., \& Kjeldsen, P. (2021). Trace gas emissions from municipal solid waste landfills: A review. Waste Management, 119, 39-62. https://doi.org/10.1016/ j.wasman.2020.09.015

Engen, T., Kuisma, J. E., \& Eimas, P. D. (1973). Short-term memory of odors. Journal of Experimental Psychology, 99 (2), 222-225. https://doi.org/10.1037/h0034645

Falchi, F., Cinzano, P., Elvidge, C. D., Keith, D. M., \& Haim, A. (2011). Limiting the impact of light pollution on human health, environment and stellar visibility. Journal of Environmental Management, 92(10), 2714-2722. https:// doi.org/10.1016/j.jenvman.2011.06.029

Fraser, H. W. (2001). Agricultural odours: 25 years of reducing complaints about barns and manure storages using the minimum distance separation formulae. Water Science and Technology, 44(9), 211-217. https:// doi.org/10.2166/wst.2001.0542

Freisthler, B., Kepple, N. J., Sims, R., \& Martin, S. E. (2013). Evaluating Medical Marijuana Dispensary Policies: Spatial Methods for the Study of Environmentally-Based Interventions. American Journal of Community Psychology, 51(1), 278-288. https://doi.org/10.1007/ s10464-012-9542-6

Frumkin, H. (2001). Beyond toxicity11The full text of this article is available via AJPM Online at www.elsevier.com/ locate/ajpmonline.: Human health and the natural environment. American Journal of Preventive Medicine, 20 (3), 234-240. https://doi.org/10.1016/S0749-3797(00) $\underline{00317-2}$

Goines, L., \& Hagler, L. (2007). Noise pollution: A modem plague. Southern Medical Journal, 100(3), 287-294. https://doi.org/10.1097/smj.0b013e3180318be5

Gostelow, P., Parsons, S. A., \& Stuetz, R. M. (2001). Odour measurements for sewage treatment works. Water Research, 35(3), 579-597. https://doi.org/10.1016/S0043$\underline{1354(00) 00313-4}$

Government of Canada. (2016). Understanding the New Access to Cannabis for Medical Purposes Regulations. Health Canada.

Government of Canada. (2019). ARCHIVED - market data under the Access to Cannabis for Medical Purposes Regulations.

Government of Canada. (2021, January 15). Licensed cultivators, processors and sellers of cannabis under the Cannabis Act.

Government of Ontario. (2019). Minimum Distance
Separation (MDS) Formulae.

Grant, J. L., Filion, P., Habib, A., Manuel, P., \& Rapaport, E. (2013). Coordinating land use planning in the context of multiple plans.

Hewitt, S. (2016). "While Unpleasant it is a Service to Humanity":The RCMP's War on Drugs in the Interwar Period. Journal of Canadian Studies. https:// doi.org/10.3138/jes.38.2.80

Hölker, F., Moss, T., Griefahn, B., Kloas, W., Voigt, C. C., Henckel, D., ... Tockner, K. (2010). The Dark Side of Light: A Transdisciplinary Research Agenda for Light Pollution Policy. Ecology and Society, 15(4).

Krishnan, U. (1995). Development of methods to identify and quantify selected odor causing compounds. Iowa: Iowa State University.

Lalge, A., Cerny, P., Trojan, V., \& Vyhnanek, T. (2017). The effects of red, blue and white light on the growth and development of Cannabis sativa L. 24(1), 646-651.

Lane, W. N., \& McDonald, R. R. (1983). Land Suitability Analysis: Landfill Siting. 50-61.

MacMillan, W. R., \& Fraser, H. (2003). Toward a sciencebased agricultural odour program for Ontario: A comparison of the mds and offset odour setback systems. Air Pollution from Agricultural Operations III, Proceedings of the 12-15 October 2003 Conference, 336345. St. Joseph: American Society of Agricultural and Biological Engineers. https://doi.org/10.13031/2013.15527

Mendocino County. (n.d.). CHAPTER 10A.17 - MENDOCINO CANNABIS CULTIVATION ORDINANCE.

Mahin, T. D. (2001). Comparison of different approaches used to regulate odours around the world. Water Science and Technology, 44(9), 87-102. https://doi.org/10.2166/ wst.2001.0514

McKendry, P., McKenzie, A., \& Looney, J. H. (2003). Managing Odour Risk at Landfill Sites: Main Report.

Ministry of the Environment Sewage Technical Working Group. (2019, May 3). Design Guidelines For Sewage Works.

National Organization for the Reform of Marijuana Laws. (2019). NORML.

Navara, K. J., \& Nelson, R. J. (2007). The dark side of light at night: Physiological, epidemiological, and ecological consequences. Journal of Pineal Research, 43(3), 215224. https://doi.org/10.1111/j.1600-079X.2007.00473.x

Nemeth, J., \& Ross, E. (2014). Planning for Marijuana: The Cannabis Conundrum. Journal of the American Planning Association, 80, 6-20. https:// doi.org/10.1080/01944363.2014.935241

Nimmermark, S. (2004). Odour influence on well-being and 


\section{Cannabis production land use planning in Canada}

health with specific focus on animal production emissions. Annals of Agricultural and Environmental Medicine: AAEM, 11, 163-173.

Norfolk County. (2014). Norfolk County Zoning By-Law.

Oiamo, T. H., Luginaah, I. N., \& Baxter, J. (2015). Cumulative effects of noise and odour annoyances on environmental and health related quality of life. Social Science \& Medicine, 146, 191-203. https:// doi.org/10.1016/j.socscimed.2015.10.043

Ontario Ministry of Environment. (2012, January). Landfill standards: A guideline on the regulatory and approval requirements for new or expanding landfilling sites.

Osler, Hoskin \& Harcourt LLP. (2021, January 21). Municipal land use planning and development

Owens, B. (2019, August 28). The professionalization of cannabis growing. Nature.

Parcsi, G. (2010). Chemical analysis of odorants from poultry facilities. (Ph.D. Dissertation). University of New South Wales, South Wales.

Pauley, S. M. (2004). Lighting for the human circadian clock: Recent research indicates that lighting has become a public health issue. Medical Hypotheses, 63(4), 588-596. https:// doi.org/10.1016/j.mehy.2004.03.020

Persaud, K., \& Dodd, G. (1982). Analysis of discrimination mechanisms in the mammalian olfactory system using a model nose. Nature, 299(5881), 352-355. https:// doi.org/10.1038/299352a0

Potter, D. J. (2014). Cannabis Horticulture. In R. Pertwee (Series Ed.), Handbook of Cannabis (pp. 65-70). Oxford University Press.

Public Health Ontario. (2018). Evidence Brief: Odours from cannabis production.

Queirolo, R., Boidi, M. F., \& Cruz, J. M. (2016). Cannabis clubs in Uruguay: The challenges of regulation. International Journal of Drug Policy, 34, 41-48. https:// doi.org/10.1016/j.drugpo.2016.05.015

Reid, M., \& Dykstra, L. (2016). An Introduction to the New Access to Cannabis for Medical Purposes Regulations (ACMPR).

Rice, S., \& Koziel, J. A. (2015). Characterizing the Smell of Marijuana by Odor Impact of Volatile Compounds: An Application of Simultaneous Chemical and Sensory Analysis. PLOS ONE, 10(12), e0144160. https:// doi.org/10.1371/journal.pone. 0144160

Ritter, W. F. (1989). Odour control of livestock wastes: Stateof-the-art in North America. Journal of Agricultural Engineering Research, 42(1), 51-62. https:// doi.org/10.1016/0021-8634(89)90039-5

Romain, A.-C., Delva, J., \& Nicolas, J. (2008).
Complementary approaches to measure environmental odours emitted by landfill areas. Sensors and Actuators B: Chemical, 131(1), 18-23. https://doi.org/10.1016/ j.snb.2007.12.005

Salkin, P. E., \& Kansler, Z. (2010). Medical Marijuana Meets Zoning: Can You Grow, Sell, and Smoke That Here? Planning \& Environmental Law, 62(8), 3-8. https:// doi.org/10.1080/15480755.2010.507506

Schiffman, S. S., \& Williams, C. M. (2005). Science of Odor as a Potential Health Issue. Journal of Environmental Quality, 34(1), 129-138. https://doi.org/10.2134/ jeq2005.0129a

Sedlock, R., \& Settelmeyer, J. (2017, November 3). Living near marijuana grow can be unhealthy experience.

Shinwari, Z. K., Tanvir, M., \& Yusuf, O. (2015). Protein estimation and palynlogical studies of cannabis sativa 1 . Pollen in relation to respiratory allergies. Pakistan Journal of Botany, 47(4), 1517-1520.

Shusterman, D. (1999). The health significance of environmental odour pollution: Revisited. Journal of Environmental Medicine, 1(4), 249-258. https:// doi.org/10.1002/jem.38

Stellacci, P., Liberti, L., Notarnicola, M., \& Haas, C. N. (2010). Hygienic sustainability of site location of wastewater treatment plants: A case study. I. Estimating odour emission impact. Desalination, 253(1), 51-56. https://doi.org/10.1016/j.desal.2009.11.034

Steiner, L. (2018). Growing at Home: Health and Safety Concerns for Personal Cannabis Cultivation. National Collaborating Centre for Environmental Health.

Stuart-Ulin, C. R. (2019). Growing Pains. Maisonneuve, (73), 29-37.

van Lier, H. N. (1998). The role of land use planning in sustainable rural systems. Landscape and Urban Planning, 41(2), 83-91. https://doi.org/10.1016/S0169-2046(97) 00061-3

Vaughan, M. (2018). Cannabis Production and Processing Policy Review D.C.S. 18-06. Norfolk County: Norfolk Country.

Walsh, J., \& Ramsey, G. (2018). Cannabis Regulation in Uruguay: An Innovative Law Facing Major Challenges. Journal of Drug Policy Analysis, 11(1). https:// doi.org/10.1515/jdpa-2015-0007

Zhang, Q., Feddes, J., Edeogu, I., Nyachoti, M., House, J., Small, D., ... Clark, G. (2002). Odour production, evaluation and control. Manitoba Livestock Manure Management Initiative Inc.

Zuardi, A. W. (2006). History of cannabis as a medicine: A review. Brazilian Journal of Psychiatry, 28(2), 153-157. https://doi.org/10.1590/S1516-44462006000200015 